\title{
How Do Management Fees Affect Retirement Wealth Under Mexico's Personal Retirement Accounts System?
}

Emma Aguila, Michael D. Hurd, Susann Rohwedder

RAND Labor \& Population

WR-1023

December 2013

This paper series made possible by the NIA funded RAND Center for the Study of Aging (P3OAG012815) and the NICHD funded RAND Population Research Center (R24HD050906).

RAND working papers are intended to share researchers' latest findings and to solicit informal peer review. They have been approved for circulation by RAND Labor and Population but have not been formally edited or peer reviewed. Unless otherwise indicated, working papers can be quoted and cited without permission of the author, provided the source is clearly referred to as a working paper. RAND's publications do not necessarily reflect the opinions of its research clients and sponsors. RAND® is a registered trademark. 


\title{
How Do Management Fees Affect Retirement Wealth Under Mexico's Personal Retirement Accounts System?
}

\author{
Emma Aguila, Michael D. Hurd, Susann Rohwedder* \\ RAND
}

\begin{abstract}
In 1997, Mexico transformed its pay-as-you-go social-security system to a fully funded system with personal retirement accounts, including management fees. In this paper, we examine changes in retirement wealth resulting from this new system. We found management fees drained a significant proportion of individuals' retirement wealth and had the effect of increasing the number of persons claiming a government-subsidized minimum pension, particularly from the time the system was introduced in 1997 until adjustment to management fees in 2008. Since 2008 , retirement wealth accumulation has been similar to that of the previous system.
\end{abstract}

Keywords: Retirement wealth accumulation, retirement fund management fees, social security reform, Mexico

JEL classification: $\mathrm{H} 55, \mathrm{G} 23, \mathrm{~J} 32$

* Emma Aguila, RAND Corporation, 1776 Main Street, Santa Monica, CA 90401-3208, (310) 393-0411, x6682,Emma_Aguila@rand.org; Michael D. Hurd, RAND Corporation, 1776 Main Street, Santa Monica, CA 90401-3208, (310) 393-0411, x6945, Michael_Hurd@rand.org; Susann Rohwedder, RAND Corporation, 1776 Main Street, Santa Monica, CA 90401-3208, (310) 393-0411, x78825, Susann_Rohwedder@rand.org. This study was supported by a grant from the U.S. Social Security Administration (SSA) funded as part of the Retirement Research Consortium (RRC) and the National Institute of Aging (NIA) funded program project "International Comparisons of Well-Being, Health and Retirement" 2P01AG022481-06. We thank Nelly Mejia and Alfonso Rivera for their excellent research assistance.

The findings and conclusions expressed are solely those of the author(s) and do not represent the views of the Social Security Administration, any agency of the Federal government, or the Michigan Retirement Research Center. 


\section{Introduction}

To expand coverage of pension systems to more persons and contain the costs of doing so, many countries are contemplating or have already enacted pension reforms. In 1997, Mexico reformed its pay-as-you-go (PAYG) social-security system to a fully funded, personal-retirement accounts (PRA) system. Such systems are increasingly replacing PAYG systems throughout the world because they are considered to be more financially sustainable. This is particularly important in Mexico where, among persons at least 65 years of age and according to the National Council for the Evaluation of Social Development Policy (CONEVAL), about half are in poverty and more than one in four did not have any access to social security. ${ }^{1}$

In this paper, we compare how Mexican workers fare on accumulated pension wealth in the old PAYG and the new PRA systems. We pay particular attention to how PRA-system fees have affected retirement wealth accumulation. We use administrative data from the Mexican National Commission for the Pension System (Comisión Nacional del Sistema de Ahorro para el Retiro, or CONSAR), the regulatory agency of the PRA system, to simulate retirement wealth under the rules of the PRA system and the previous PAYGO system, including before and after the 2008 reform to the fees structure. Examining experiences with PRA schemes in other countries can help policymakers determine whether this option is appropriate for their country, if so, help them avoid some pitfalls of previous implementations.

The PRA design in Mexico rests on three pillars: first, a minimum pension guarantee by the government; second, personal retirement accounts managed by private retirement fund managers; and third, voluntary retirement saving accounts with tax advantages such as those

\footnotetext{
${ }^{1}$ More than half of the labor force in Mexico is in the informal sector and do not contribute to the social security system. Individuals in the informal sector some receive a noncontributory pension government subsidy, which is a flat rate lower than the minimum pension guaranteed of the social security system (Aguila et al., 2011).
} 
available in the United States through 401(k) plans and Individual Retirement Accounts (IRAs). While the previous PAYG system made the government bear all risk, Mexico's PRA system distributes risk more broadly. The government bears the risk for the first pillar, the minimum pension guarantee, but employees bear risks for the second and third pillars, the personal retirement accounts and the voluntary retirement saving accounts.

The personal retirement accounts have management fees. Previous studies have found that retirement-fund management fees in Mexico are the highest among the Latin American and OECD countries, eroding from 18 percent to 23 percent of the total accumulated retirement benefits (see, for example, James et al., 2001; Kritzer et al., 2011; Kritzer, 2000; and Dobronogov and Murthi, 2005).

Also previous research, analyzes behavioral responses to incentives to contribute to voluntary retirement accounts such as 401k's in the United States (see, for example, Benartzi and Thaler, 2001; Madrian and Shea, 2001; Choi, Laibson, Madrian, and Metrick, 2003; Choi, Laibson, Madrian, and Metrick, 2005; Beshears, Choi, Laibson, and Madrian, 2013). This paper analyzes a mandatory social security system with retirement accounts managed by pension fund managers and the investment portfolio and management system fees are highly regulated by the government. In this case, retirement funds with high management fees may deplete savings to the extent that individuals receive a minimum pension guarantee - and thereby increase government fiscal cost for retirement programs.

Altogether, we find that, average retirement fund manager fees could drain retirement wealth by nearly 6 percent of what would have been accumulated with the lowest-fee manager in the market. This, in turn, would lead to the Mexican government annual spending 0.19 percent 
of GDP to subsidize pensions for low-income earners, compared to the 0.09 percent it spent for the PAYG system.

As we will discuss, changes in PRA system management fees in 2008 have helped it perform about as well as the PAYG system would have. Nevertheless, to increase accumulation of retirement wealth, the PRA scheme would require lower fees among other changes. Had the PRA system used the fee structure of the lowest-fee manager since 2008, then it would have resulted in wealth accumulation 8.4 percent greater than that in the PAYG system. In this scenario, the annual government subsidy for the minimum pension guarantee would be 0.15 percent of GDP in 2012.

While retirement-fund managers must, of course, be able to pay their costs and make a profit, management fees reduce retirement wealth accumulation. Should they reduce retirement wealth to the extent that individuals qualify for a minimum pension guarantee, they may lead individuals to comply only with the minimum requirements for the PRA system and to spend a larger proportion of their working life in the informal sector.

We organize our discussion as follows. In the next section, we discuss in more detail the management of the PRA system and the data we have on it. In the third section, we describe how we estimate retirement wealth under the PRA and PAYG systems in Mexico. In the fourth section, we analyze the impact of fees on retirement wealth accumulation in a PRA system. In the fifth section, we estimate the present value of retirement wealth under the PRA and the previous PAYG systems. In the sixth section, we conclude with some policy implications. 


\section{The Mexican PRA System and Its Management}

The performance of the PRA system depends on that of private retirement fund administrators (Administradoras de Fondos para el Retiro, or AFOREs). The AFOREs manage the personal retirement accounts of the PRA system. The rules that govern the AFORE investment portfolios restrict the proportion of funds that can be invested in the financial market apart from government bonds.

When the PRA system was introduced, there was only one authorized investment portfolio and most of its funds had to be invested in government bonds (Grandolini and Cerda, 1998). Since 2001, the maximum proportion of funds that could be invested in the domestic market has increased. Investment in international financial instruments was not allowed until April 2005. In September 2012, 57.0 percent of AFORE portfolios were still invested in government bonds (CONSAR, 2012), making the government the principal recipient of retirement funds (Sánchez Daza and De la Luz Juárez, 2008). This hinders competition between retirement fund managers because it makes it more difficult for them to differentiate themselves by providing more attractive real returns (Mesa-Lago, 2002; Sinha, 2002).

Several previous studies have suggested that the highly regulated nature of portfolio investment may explain the lack of a link between the rates of return and management fees (Kritzer, 2000; Sinha, 2002; Mesa-Lago, 2002; Gutierrez, Serra and Fischer, 2003; Arenas de Mesa and Mesa-Lago, 2006; Sánchez Daza and De la Luz Juárez, 2008). In this study, we focus on understanding how management fees affect the accumulation of social security wealth. Because prior studies have documented that rates of return and management fees are unrelated, we conduct our analyses assuming a fixed interest rate (Dobronogov and Murthi, 2005; Sinha, 2002). For robustness, we simulate retirement wealth with different interest rate scenarios. 
From July 1997 until February 2008, AFOREs charged three types of management fees: a load factor, fees on the balance of the account, and fees on the accrued interest. Since March 2008, the PRA system has allowed AFOREs only to charge a fee on the account balance. The CONSAR data we analyze include information for all thirty-two AFOREs that have operated at any time since the PRA system was established, 13 of which were still operating in November 2012. While fees vary by AFORE, each AFORE charges the same fees to each of its investment portfolios.

\section{Accrued Interest Fee}

A few AFOREs had accrued-interest fees between 1998 and 2003. In May 1998, only two AFOREs of 19 then operating had accrued-interest fees: Atlantico Promex, with a 20-percent fee, and Inbursa, with a 33-percent fee. In November 1998, Atlantico Promex merged with another AFORE, leaving Inbursa as the only one with a fee on accrued interest until March 2003. Inbursa dropped this fee, and no other AFORE charged it before it was banned in 2008.

\section{Load Factor Fee}

PRA load factor fees are calculated as the percentage of the total wage on which the worker paid a retirement contribution, rather than as the percentage of the contribution, as is customary in the United States. This makes them appear small, when in fact they translate into high fees. Consider, for example, a worker who earns $\$ 1,000$. Total contributions amount to 6.5 percent of the wage or $\$ 65$. A load factor fee of 1 percent is applied to the contributed amount divided by 6.5 percent (that is, to the income): $(\$ 65 / 0.065) \times 1$ percent $=\$ 10$. In the United States, this would be considered a load-factor fee of 15.4 percent (e.g., $\$ 10$ is 15.4 percent of \$65). Similarly, a load factor of 1.5 percent in the Mexican PRA system is equivalent to a load factor of 23.0 percent in the United States. 
In December 1999, load factor fees for AFOREs (see Figure 1 panel a) were between 0 and 1.7 percent. By the end of 2002, mean load factor fees started to decrease and the highest fee in the market was offered by AFORE Banamex. More frequent and transparent information may have led to this reduction. In late 2002, AFOREs began sending PRA statements at least twice rather than once yearly. In 2002, AFOREs also had to provide information about their fees and employee contributions on such statements. At the same time, the mechanism to switch between AFOREs became more flexible. As a result, employees increasingly switched between AFOREs, and competition among AFOREs to retain or attract clients may have led them to reduce their fees. In particular, employees increasingly favored AFOREs that had the highest market share, were most advertised, or were most available in an individual's hometown (Calderón-Colín, Dominguez and Schwartz, 2008; Prieto, 2005).

In November 2005, the regulatory framework changed to include penalties for AFOREs in response to a large volume of complaints about incorrect fee application and insufficient information about individual accounts. ${ }^{2}$ This may have reduced customer trust in AFORE operations. AFOREs may have reduced their fees in response; by December 2007, load factor fees were between 0.5 percent and 1.6 percent, with the average and median both below 1.0 percent. $^{3}$

\footnotetext{
${ }^{2}$ Retirement Saving System Law ("Ley de los Sistemas de Ahorro para el Retiro," 1996), Article 100.

${ }^{3}$ Some pension fund managers also provided discounts on their load factor fees according to tenure in the fund. The first AFOREs to implement such discount schemes were Banamex and Bancomer. These discounts consisted mainly of decreasing load factor fees by 0.01 percent, 0.02 percent, or 0.05 percent per year after being with the same fund for two to five years. By 2006, most AFOREs had adopted discount schemes to increase customer loyalty by making switching more costly. Some AFOREs completely eliminated the load factor fee after 25 years of tenure. After February 2008, when only the balance fee was allowed, the discount scheme was eliminated.
} 


\section{Figure 1}

Evolution of management fees, 1998 to 2012



(a) Load factor fee

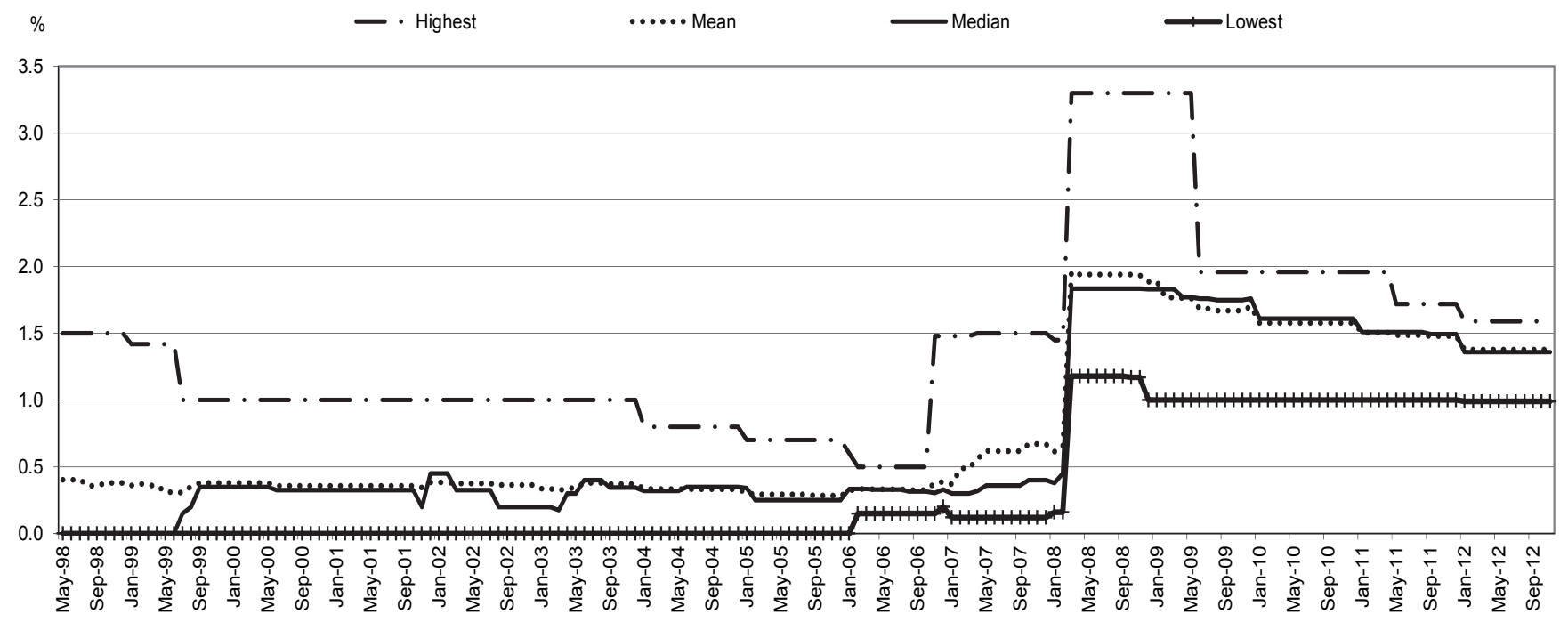

(b) Balance fee

SOURCE: Authors' calculation using data from Comisión Nacional del Sistema de Ahorro para el Retiro (CONSAR), 2012

NOTEs: Load factor fees are computed as a percentage of a worker's wage. Balance fees are an annual percentage. 


\section{Balance Fee}

In May 1998, balance fees were between 0 percent and 1.5 percent (Figure 1 panel b)with most AFOREs not charging such a fee. Balance fees began to decrease in December 1999, converging to an average of 0.39 percent in December 2006. Many more AFOREs introduced balance fees in March 2003; by February 2006 most AFOREs had a balance fee. In late 2006, the Banamex AFORE increased its balance fee from 0.34 percent to 1.48 percent, and most other

AFOREs increased their balance fees as well. These fees increased even more after the regulatory framework abolished all other fees in February 2008, with the range then reaching 1.1 percent to 3.3 percent. Balance fees began to decrease in January 2009, falling to a minimum of 0.99 percent and a maximum of 1.59 percent by November 2012. The latter may indicate that regulatory simplification does not necessarily increase competition between pension fund managers.

\section{Estimating Retirement Wealth in the Mexican PAYG and PRA Systems}

To qualify for social security benefits under the PRA system, a worker must contribute for at least 1,250 weeks, or approximately 25 years. The PAYG required only 500 weeks, or approximately 10 years, of contributions. The normal retirement age is 65 in both plans. In the

PRA system, early retirement is possible at age 60 if a worker has a sufficient balance to obtain retirement benefits at least matching the minimum pension guarantee. Retirement prior to age 60 is available if a worker has a sufficient PRA balance to obtain retirement benefits at least 130 percent of the minimum pension guarantee. In the PAYG system, for each year before age 65 that one retires after age 60 , retirement benefits are reduced by 5 percent; for example, those retiring at age 60 receive 75 percent of normal retirement benefits (Aguila, 2012). 
Contributions to the social security system are defined as a percentage of the worker's wage. The employer, employee, and government contribute to the social security system. The employee and employer contributions did not change after the social security system reform of 1997, remaining combined at 6.275 percent of a worker's wage (Aguila, 2011). We compute PAYG social security benefits as

$$
P^{P A Y G}=\left[\delta(\bar{w})^{*} \bar{w}+\alpha^{*}(c y-10)^{*} \lambda(\bar{w})^{*} \bar{w}\right]
$$

where $\delta(\bar{w})$ is the replacement rate for the first 10 years of contribution to the PAYG system, $\lambda(\bar{w})$ is the replacement rate for every year of contribution after the first 10 years, $\bar{w}$ is the average wage of the five years prior to retirement, $c y$ is the years of contribution to the social security system, and $\alpha$ indicates if the individual has contributed more than 10 years to the social security system.

Like the PAYG system, the PRA system in Mexico has some redistributive components. First, the government deposits a monthly social quota in each individual account, equivalent to 5.5 percent of the minimum wage in Mexico City. Second, as noted earlier, the government offers a minimum pension guarantee, equivalent to the minimum wage in Mexico City. The federal government also contributes 0.425 percent of a worker's wage to his or her account (Aguila, 2011). Thus, employees and the government share the financial risk in Mexico's PRA system.

We compute PRA social security benefits from the balance in the individual account, which depends on the contribution rate $c=c_{e}+c_{e m}+c_{g}$, the employee contribution rate $c_{e}$, the employer contribution rate $c_{e m}$, and the government contribution rate $c_{g}$, all expressed as a percentage of the worker's monthly wage $w_{t}$ in month $t$. The government contribution also includes, as noted earlier, a fixed redistributive component (Social Quota). These contributions 
are calculated monthly but are deducted from the worker's wage and deposited in the AFOREs on a bimonthly basis. The balance of a PRA also depends on the fees charged by retirement-fund managers as described above. The PRA system has had, as noted, three types of management fees: load factor $\left(f e e_{l f}\right)$, discontinued in 2008, accrued interest $\left(f e e_{r}\right)$, discontinued in 2003, and balance fee $\left(f e e_{b}\right)$. PRA account performance also depends on the monthly rate of return $r$ and the monthly periods of contribution to the system $K$.

Because the contributions are deposited bimonthly, but the balance and the interest fees are charged monthly, we compute the account balance of the PRA retirement benefits without management fees at time $K$ for a worker that has worked a total of $K$ months and makes bimonthly contributions as

$$
\begin{aligned}
P_{K}^{c}=\left[\left(w_{1}+w_{2}\right)\right. & * c+2 * \text { Social Quota }](1+r)^{K-2} \\
& +\left[\left(w_{3}+w_{4}\right) * c+2 * \text { Social Quota }\right](1+r)^{K-4}+\cdots \\
+ & {\left[\left(w_{K-1}+w_{K}\right) * c+2 * \text { Social Quota }\right] }
\end{aligned}
$$

We compute the accumulated monthly fees at month $K$ as

$$
P_{K}^{f}=\sum_{t=1}^{K} f e e_{t}(1+r)^{K-t}
$$

and the value of the fund at month $K P_{K}^{P R A}=P_{K}^{c}-P_{K}^{f}$. We calculate the interest-rate fee at time $t$ as $f e e_{r} r\left(P_{t}\right)$ where $f e e_{r}$ is the fee rate charged on interest earnings, and $r$ is the interest rate earned on the balance $P_{t}$. The load factor fee at time $t$ is $\left(w_{t-1}+w_{t}\right) *_{c}^{*} f e e_{l f}$ and the balance fee at time $t$ is $f e e_{b}\left(P_{t}\right)$.

Present value of PAYG and PRA Retirement Wealth 
We compute the present value of PAYG or PRA retirement benefits $\left(P V P^{j}\right)$ at the time of retirement, where $j=P A Y G, P R A$, as follows:

$$
P V P^{j}=\sum_{l=R}^{L} \frac{P^{j}}{(1+\eta)^{l-R}}
$$

Here, $L$ is the total life span in years, $P$ is the annual retirement benefits, $\eta$ is the discount rate, and $R$ is the date of retirement. ${ }^{4}$ We assume individuals retire at age 65 , make 25 years of contributions, and live 8.4 years on average after retirement. ${ }^{5}$

\section{Fees and Accumulation of Social Security Wealth in the Mexican PRA System}

As noted, retirement fund management fees have changed greatly over time. By some estimates, AFORE administrative fees have eroded 18 percent to 23 percent of total accumulated retirement wealth (Mitchell, 1999; James, Smalhout and Vittas, 2001; Mesa-Lago, 2002; Gutierrez, Serra and Fischer, 2003; Corbo, 2004; Prieto, 2005; Dobronogov and Murthi, 2005; Arenas de Mesa and Mesa-Lago, 2006; Christensen, 2007; Levy, 2008; Tapia and Yermo, 2008; Martínez and Murcia, 2008; Calderón-Colín, Dominguez and Schwartz, 2008; Hastings and Tejeda-Ashton, 2008; Kritzer, 2000; Kritzer, Kay and Sinha, 2011). Levy (2008) shows that, from 1998 to 2006, the sum of management fees obtained by the AFOREs was 1.08 times the total contribution ("social quota") of the federal government to the workers. In other words, management fees may be siphoning off the entire government subsidy.

\footnotetext{
${ }^{4}$ We used a real annual discount rate of 1 percent in the simulation. We do not compute the net present value (NPV) of retirement wealth because contribution requirements for both systems are the same.

${ }^{5}$ According to the Mexican National Population Council (Consejo Nacional de Población, or CONAPO), the life expectancy at birth of the average Mexican male in 2012 was 73.4 years. We use the life expectancy at birth instead of the life expectancy at the retirement age because the latter is not available for Mexico. We assumed that in all cases workers start to contribute when they are 40 years old and remain in the systems 25 years until they retire at age 65 . That is, the system faces the same time horizon.
} 
We assess the importance of different fees for the accumulation of retirement funds for a median worker. We use CONSAR's definition of a median worker as one with earnings three times the minimum wage; in November 2012, this was equivalent to 433 dollars per month. ${ }^{6}$

We assume a real annual rate of return of retirement funds before applying management fees of 5.0 percent. CONSAR (2012) also uses this rate to illustrate differences between AFOREs. The monthly contribution to the PRA is 6.5 percent of a worker's wage, with the additional social quota equal to 7.90 dollars per month in November 2012. All contributions are deposited bimonthly. We assume the median worker started contributing to the PRA system in May 1998, when we begin observing retirement fund management fees, and retires in 2023, after 25 years of contributions. We apply load-factor fees bimonthly as a fraction of the worker's wage and balance fees monthly.

We estimate the amount accumulated in the PRA system for a median worker facing the highest, lowest, mean, and median fees of the 32 retirement fund managers that operated at any point between May 1998 and November 2012. We apply the highest, lowest, mean, and median fees reported each period by the entire pool of fund managers, taking into account all the different types of fees. A baseline scenario assumes no management fees. We compute the loss due to management fees in each case as a percent of the balance that would have accumulated without fees. That is, for every period, we take the difference between the accumulation in a particular case of fees and the case without fees, and divide by the scenario without fees. For this exercise, we assume that the individual could use different AFOREs each period and hence consistently face the highest, lowest, mean, and median fees. Changes in the slope of the loss in retirement funds in our simulations reflect changes in management fees.

\footnotetext{
${ }^{6}$ CONSAR (2003) uses this definition to estimate and project insurance payouts. The exchange rate used here and throughout the paper, unless otherwise specified, was 13.1 pesos per dollar, which was the monthly average in
} 
Figure $2 \mathrm{a}$ presents the loss in accumulated retirement benefits as a result of accruedinterest fees and Figure $2 \mathrm{~b}$ presents the loss resulting from load-factor fees. By the time the accrued-interest fee was eliminated in 2003, those with the highest such fees had lost about 2 percent of their accumulated wealth to them. Such losses have decreased since then, but remain for some.

\section{Figure 2}

\section{Cumulative loss of pension funds for a median worker by type of fee}



November 2012, as reported by the Mexican Central Bank (Banco de México, or BANXICO, 2012). 


\section{Continued Figure 2}
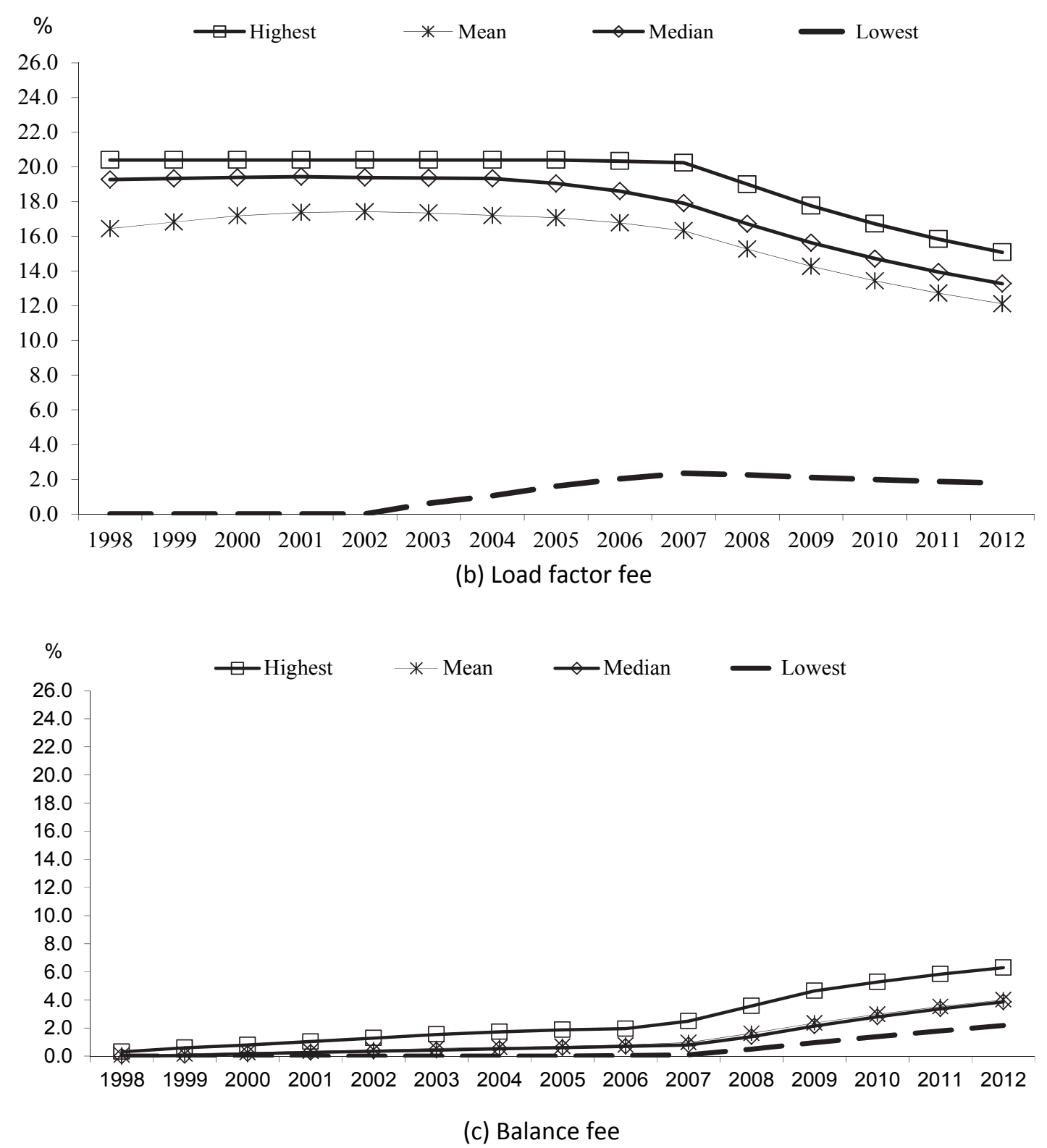

SOURCE: Authors' calculation using data from Comisión Nacional del Sistema de Ahorro para el Retiro (CONSAR), 2012.

Load factor fees create much greater losses, more than 20 percent in some circumstances. The median loss was 19.3 percent in 1998 and 16.7 percent in 2008; the mean loss in January 2008 was 16.3 percent. The loss began to decrease after the load factor fee was eliminated in 
2008. The minimum load factor fee loss was zero between 1998 and 2002 when Inbursa did not apply such a fee, but increased to 0.62 percent in 2003 and to 2.3 percent in 2008 . The highest load factor fee losses stem from charges of Banamex and Bancomer - the two AFOREs that have consistently had the highest market shares - as well as from charges of Profuturo GNP and Santander Mexicano.

Figure $2 \mathrm{c}$ shows the losses in social security wealth accumulations due to fees on the account balance are small initially but increase over time. There is substantial heterogeneity across retirement funds in such losses. Several AFOREs, such as Banamex, Bancomer, HSBC, and Inbursa, only started applying a balance fee after 2003. From 1998 to 2011, median loss increased from 0 to 3.4 percent, and highest loss increased from 0.3 to 5.8 percent; losses appeared to have accelerated in more recent years and may be a result of the elimination of other fees. Pension fund managers tried to offset the elimination of other fees by increasing the balance fee.

\section{Figure 3}

Cumulative loss of pension funds due to load factor, balance, and interest fees for a median worker

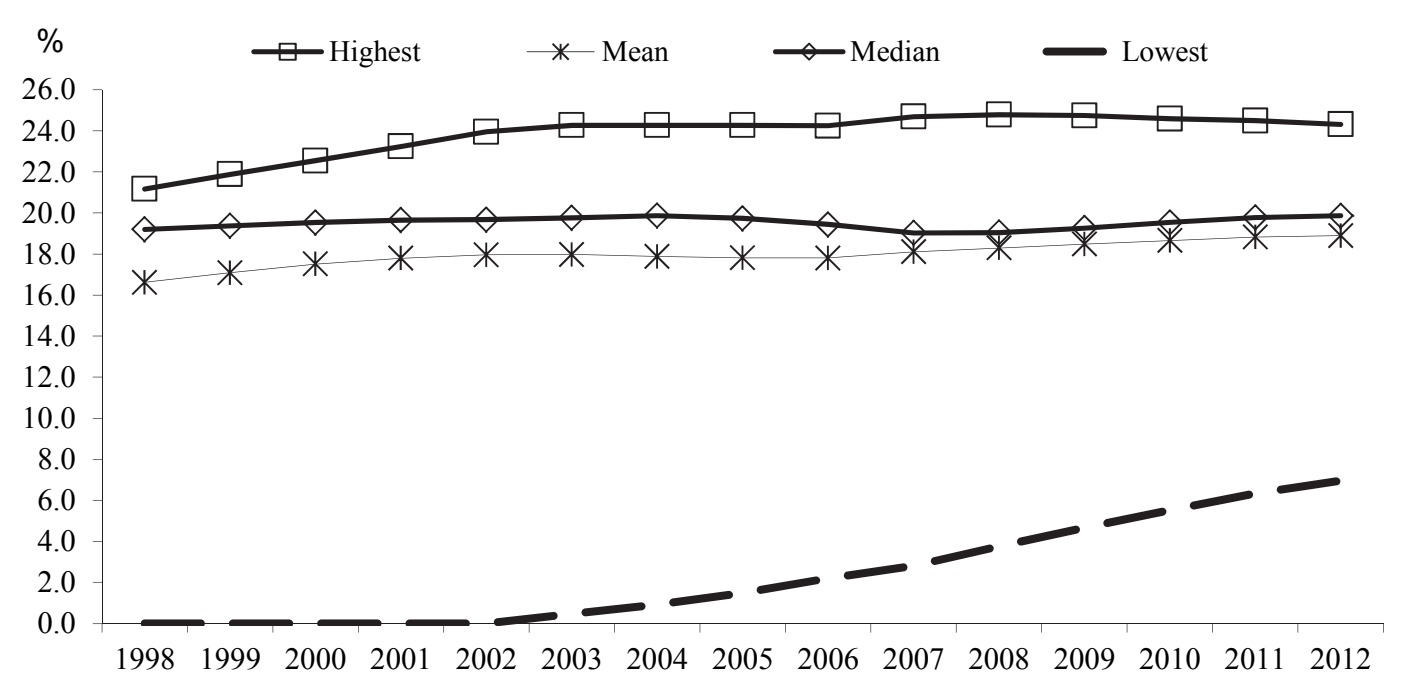

SOURCE: Authors' calculation using data from Comisión Nacional del Sistema de Ahorro para el Retiro (CONSAR), 2012. 
In Figure 3, we show the loss in retirement wealth from all fees (load factor, balance, and accrued interest fees) for a median worker. The lowest loss increased from zero to 7.0 percent in 2012, while the median loss increased from 19.2 percent to 19.9 percent, and the highest loss increased from 21.2 to 24.3 percent. While the levels of loss from the lowest-fee AFOREs have increased in recent years, those for the mean, median, and highest have stabilized or even decreased. The considerable losses in social security wealth are mainly due to the high load factor fee before February 2008 and high balance fees since then.

\section{Retirement Wealth in the Mexican PAYG and PRA Systems}

In Table 1 we show the present value of retirement benefits for the PAYG and PRA systems.

For the PRA system, we show two estimates for each of various fee scenarios: the present value of retirement benefits obtained through employee, employer, and government contributions, and the present value of retirement benefits that the government has to subsidize in order to guarantee the minimum pension for low-income workers. ${ }^{7}$ We also show scenarios for fee structures before and since 2008, reflecting the different fees permitted in those times, to assess the effects of the 2008 reform on retirement wealth.

The "representative" PRA we show in Table 1 is that with the highest number of persons registered between 1998 and 2008 and between 2008 and 2012. Specifically, the representative AFORE was the one with the maximum Share $^{h 8}$, where

\footnotetext{
${ }^{7}$ We calculate the subsidy as the difference between the minimum pension necessary to cover the life expectancy of the median worker after retirement ( 8 years) and the retirement wealth accumulated by the worker.

${ }^{8}$ We included in the analysis all AFOREs that continued providing services until November 2012. Registrants of an AFORE acquired by another are included with the acquiring AFORE.
} 


$$
\text { Share }^{h}=\frac{\sum_{t=1}^{T}\left(\frac{A_{t}^{h}}{\sum_{h=1}^{H} A_{t}^{h}}\right)}{T}
$$

and $T$ is the total months in the period (May 1998-February 2008 or March 2008-November 2012), and $A_{t}^{h}$ is the number of persons registered to the AFORE $h$ in the month $t$. In the original scheme of PRA fees, valid between 1998 and 2008, ING was the fund manager with the largest number of persons registered, averaging 19.9 percent of all registrants. ${ }^{9}$ From 2008 to 2012, Banamex had the highest market share, with an average of 16.0 percent of all registrants.

\footnotetext{
${ }^{9}$ From 1997 to 2001, no AFORE was permitted to have more than 17 percent of total registrants. Since then, no AFORE has been permitted to have more than 20 percent of registrants. See the $17^{\text {th }}$ article of the Consumer Protection Law ("Ley Federal de Protección al Consumidor") as modified by the 26th article of the Retirement Saving System Law. ("Ley de los Sistemas de Ahorro para el Retiro").
} 


\section{Table 1}

Present Value of Retirement Benefits in the PAYG and PRA plans (US dollars)

\begin{tabular}{|c|c|c|c|c|c|c|c|c|c|c|}
\hline \multirow{3}{*}{$\begin{array}{c}\text { Labor } \\
\text { income } \\
\text { (number } \\
\text { of times } \\
\text { the } \\
\text { minimum } \\
\text { wage) }\end{array}$} & \multirow{2}{*}{\multicolumn{2}{|c|}{ PAYG }} & \multicolumn{4}{|c|}{ PRA Before 2008} & \multicolumn{4}{|c|}{ PRA After 2008} \\
\hline & & & \multicolumn{2}{|c|}{ Representative Fees } & \multicolumn{2}{|c|}{ Lowest Fees } & \multicolumn{2}{|c|}{ Representative Fees } & \multicolumn{2}{|c|}{ Lowest Fees } \\
\hline & $\begin{array}{l}\text { Retirement } \\
\text { wealth }\end{array}$ & $\begin{array}{c}\text { Retirement } \\
\text { wealth } \\
\text { from taxes } \\
\text { (pension } \\
\text { guarantee) }\end{array}$ & $\begin{array}{l}\text { Retirement } \\
\text { wealth from } \\
\text { contributions }\end{array}$ & $\begin{array}{c}\text { Retirement } \\
\text { wealth } \\
\text { from taxes } \\
\text { (pension } \\
\text { guarantee) }\end{array}$ & $\begin{array}{l}\text { Retirement } \\
\text { wealth from } \\
\text { contributions }\end{array}$ & $\begin{array}{l}\text { Retirement } \\
\text { wealth } \\
\text { from taxes } \\
\text { (pension } \\
\text { guarantee) }\end{array}$ & $\begin{array}{l}\text { Retirement } \\
\text { wealth from } \\
\text { contributions }\end{array}$ & $\begin{array}{l}\text { Retirement } \\
\text { wealth } \\
\text { from taxes } \\
\text { (pension } \\
\text { guarantee) }\end{array}$ & $\begin{array}{l}\text { Retirement } \\
\text { wealth from } \\
\text { contributions }\end{array}$ & $\begin{array}{l}\text { Retirement } \\
\text { wealth } \\
\text { from taxes } \\
\text { (pension } \\
\text { guarantee) }\end{array}$ \\
\hline 1 & 13,204 & 1,780 & 11,445 & 3,539 & 11,587 & 3,397 & 11,149 & 3,835 & 11,915 & 3,069 \\
\hline 2 & 18,263 & 0 & 18,222 & 0 & 18,846 & 0 & 18,261 & 0 & 19,442 & 0 \\
\hline 3 & 25,691 & 0 & 25,000 & 0 & 26,104 & 0 & 25,373 & 0 & 26,969 & 0 \\
\hline 4 & 31,697 & 0 & 31,778 & 0 & 33,362 & 0 & 32,485 & 0 & 34,496 & 0 \\
\hline · & · & & - & · & • & - & - & · & - & - \\
\hline$\cdot$ & $\cdot$ & & $\cdot$ & $\cdot$ & · & - & • & - & • & • \\
\hline . & . & & . & . & . & . & . & . & . & . \\
\hline 18 & 130,369 & 0 & 126,665 & 0 & 134,978 & 0 & 132,053 & 0 & 139,873 & 0 \\
\hline 19 & 137,612 & 0 & 133,443 & 0 & 142,236 & 0 & 139,165 & 0 & 147,400 & 0 \\
\hline 20 & 144,855 & 0 & 140,221 & 0 & 149,495 & 0 & 146,276 & 0 & 154,927 & 0 \\
\hline$\cdot$ & $\cdot$ & & • & • & • & - & - & $\cdot$ & • & - \\
\hline - & $\cdot$ & & - & - & • & - & - & - & • & - \\
\hline . & . & & . & . & . & . & . & . & . & . \\
\hline $\begin{array}{c}\text { Average } \\
\text { proportion } \\
\text { of pension } \\
\text { compared } \\
\text { to the } \\
\text { PAYG } \\
\text { case* } \\
\end{array}$ & 0.0 & & -0.8 & & 4.8 & & 2.5 & & 8.4 & \\
\hline
\end{tabular}


For a worker earning minimum wage, the present value of accumulated retirement wealth in the PAYG system is $\$ 13,204$, plus $\$ 1,780$ received as a subsidy from the government to reach the minimum pension guarantee. Under the PRA system, the minimum-wage worker accumulates $\$ 11,445$ if contributing to the representative AFORE and receives an additional $\$ 3,539$ from the government's subsidy. Under the 2008 reforms, the minimum-wage worker contributing to the representative AFORE will accumulate $\$ 11,149$ and receive an additional subsidy of $\$ 3,835$.

We find that, for all levels of labor income, individuals would have been better off in the PAYG system than they would have been in the pre-2008 PRA system but not in the system since then. ${ }^{10}$ The amount accumulated in the PRA system depends on the performance of the real interest rate as well. We find that the PAYG system provides higher retirement wealth than the PRA scheme in most cases, when the real rate of return is below 5.1 percent before 2008 and below 4.8 percent since then. The observed average real rate of return, estimated as the difference between the monthly average rate of return of the government bonds at 28 days and monthly inflation, was 9.6 percent for the period 1997-2012; 11.8 percent between 1997 and 2007; and 4.9 percent between 2008 and 2012. That is, the observed real interest rate of return suggests that the scenarios in which contributors are better off in the post 2008 PRA system is achievable.

Within the PRA-system fee scenarios, the worse option for workers earning more than three times the minimum wage was the original scheme with load-factor, balance, and accrued-

\footnotetext{
${ }^{10}$ In the PAYG system, the minimum pension guarantee was indexed to adjustments in the minimum wage from 1997 to 2002 and to changes in inflation since then. The PRA minimum pension guarantee is subject to changes in inflation. For ease of interpretation, we only present in Table 1 the estimates of the present value of retirement benefits of the PAYG system for the minimum pension guarantee adjusted with inflation.
} 
interest fees. While the load-factor fee was eliminated in 2008 , the balance fee increased substantially. As a result, retirement wealth accumulation increased only slightly. Eliminating load-factor fees eliminated an important drain on retirement wealth and helped retirement wealth increase, to that of the PAYG system, despite the increase in the balance fee. The average loss of total retirement wealth in the 25 years of contribution under the representative fees of the PRA system before 2008 was 0.8 percent higher than in the PAYG system, while since then the PRA system has yielded on average 2.5 percent more than the PAYG system.

The average loss of retirement wealth between the representative-fee system and the retirement wealth that would have been accumulated in the PRA system with no fees was 14.5 percent for the fee structure after 2008 , in comparison to 17.2 percent in the scenario with the pre-2008 fee structure. Therefore, the 2008 reform achieved only a minor reduction in the fees and, subsequently, a minor increase in retirement wealth accumulation.

We also compared the gap of the social security wealth accumulation of the AFOREs with the lowest and highest fees in each system. In the pre-2008 regime, the lowest fees would have increased social security wealth accumulation 5.6percent more than the representative AFORE. The highest fees would have drained 5.1percent more than the representative AFORE would (case of highest fees not shown in Table 1). ${ }^{11}$ In the post-2008 regime, the lowest-fee

\footnotetext{
${ }^{11}$ To obtain the AFOREs with the mean, least, and most expensive fees, we estimated the average of each of their fees by period (before and after 2008) and then applied the formula to obtain the PRA present value of retirement benefits. For AFOREs that received registrants from AFOREs they acquired, we estimated average management

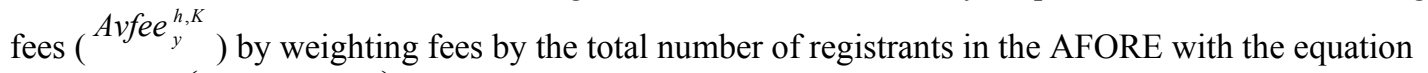$$
A v f e e_{y}^{h, K}=\frac{\sum_{t=1}^{T}\left(\frac{\sum_{k=1}^{K}\left(f e e_{y, t}^{k} * A_{t}^{k}\right)}{\sum_{k=1}^{K} A_{t}^{k}}\right)}{T}
$$

where $^{f e e_{y, t}^{k}}$ is the management fee of type $y$ (load factor, accrued interest, or balance fee) in month $t$ of the fund manager $k$ that merged to AFORE $h$, and $A_{t}^{k}$ are the persons registered to AFORE $k$ in month $t$. We found Inbursa yielded the lowest loss pension in the original PRA-fee scheme and Profuturo GNP produced the highest loss. From
} 
schemes would have accumulated 8.4 percent more than the PAYG scheme and 5.9 percent more than the representative AFORE. The highest-fee schemes would have diminished wealth accumulation by 5.0 percent compared the representative AFORE and by 2.5 percent compared to the PAYG regime.

We also compared the gap of the social security wealth accumulation of the AFOREs with the lowest and highest fees in each system. In the pre-2008 regime, the lowest fees would have increased social security wealth accumulation 4.6 percent more than the representative AFORE. The highest fees would have drained 4.2 percent more than the representative AFORE would (case of highest fees not shown in Table 1). ${ }^{12}$ In the post-2008 regime, the lowest-fee schemes would have accumulated 8.4 percent more than the PAYG scheme and 4.9 percent more than the representative AFORE. The highest-fee schemes would have diminished wealth

1998 to 2008, Inbursa, applied a load factor fee of 0.25 percent, an accrued-interest fee of 17.1 percent, and a balance fee of 0.24 percent, while Profuturo GNP applied a load-factor fee of 1.65 percent, no interest fee, and a 0.69 percent balance fee. The mean loss of present value of retirement wealth between Inbursa and Profuturo GNP was 8.4 percent. Since 2008, ISSSTE has had the least-expensive fee scheme, with a balance fee of 1 percent, and Coppel the most-expensive, with an average balance fee of 2.24 percent. The gap in terms of loss of retirement wealth between the least and most expensive AFOREs was approximately 9.4 percent.

${ }^{12}$ To obtain the AFOREs with the mean, least, and most expensive fees, we estimated the average of each of their fees by period (before and after 2008) and then applied the formula to obtain the PRA present value of retirement benefits. For AFOREs that received registrants from AFOREs they acquired, we estimated average management



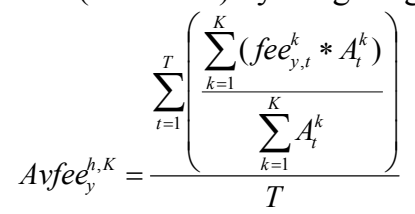

where $f e e_{\xi, t}^{k}$ is the management fee of type $y$ (load factor, accrued interest, or balance fee) in month $t$ of the fund manager $k$ that merged to AFORE $h$, and ${ }^{A_{t}^{k}}$ are the persons registered to AFORE $k$ in month $t$. We found Inbursa yielded the lowest loss pension in the original PRA-fee scheme and Profuturo GNP produced the highest loss. From 1998 to 2008, Inbursa, applied a load factor fee of 0.25 percent, an accrued-interest fee of 17.1 percent, and a balance fee of 0.24 percent, while Profuturo GNP applied a load-factor fee of 1.65 percent, no interest fee, and a 0.69 percent balance fee. The mean loss of present value of retirement wealth between Inbursa and Profuturo GNP was 8.4 percent. Since 2008, ISSSTE has had the least-expensive fee scheme, with a balance fee of 1 percent, and Coppel the most-expensive, with an average balance fee of 2.24 percent. The gap in terms of loss of retirement wealth between the least and most expensive AFOREs was approximately 9.4 percent. 
accumulation by 4.1 percent compared the representative AFORE and by 2.5 percent compared to the PAYG regime.

In other words, the present value of retirement wealth of the PRA with the representative AFORE is less than that of the least expensive fee scheme but more than that of the most. The AFORE with the highest market share does not apply the lowest (or highest) management fees. Calderón-Colín, Dominguez, and Schwartz (2008) suggest the Mexican worker is unable to effectively evaluate the performance of his AFORE, leading to inelasticity in demand with respect to price. They note, for example, that 53 percent of workers who switched AFOREs in 2006 lost retirement wealth doing so.

The most expensive AFORE can drain nearly 25 percent of retirement wealth in both the pre-2008 and the post-2008 fee schemes (results not shown). High management fees also affect low-income workers and the government. As noted, gaps between accumulated retirement wealth and the minimum pension guarantee activates the redistributive component of the PRA system, with the government paying the difference (Gill et al., 2005). High management fees could impose high costs on the government when it must ensure the minimum pension guarantee to a larger number of workers whose PRA savings fall short (Mitchell, 1999).

To ensure retiring workers have a pension worth at least the minimum guarantee, we find the government must subsidize 11.9 percent of the social security wealth in the PAYG system, 23.6 percent in the pre-2008 PRA system, and 25.6 percent in the post-2008 PRA system. This annual subsidy would be equivalent to 0.09 percent of the GDP in 2012 for the PAYG system, 0.18 percent in the pre-2008 PRA system, and 0.19 in the post-2008 PRA system. ${ }^{14}$ The annual

\footnotetext{
${ }^{13}$ We obtained the percentage of the tax burden of the new system with respect to the case with no fees using the formula

$$
\left(\frac{\left(T B_{f}^{D C}-T B_{n f}^{D C}\right) * C_{1 m w} * 100}{G D P}\right) / L E x p
$$
}


government subsidy is higher for the post-2008 PRA system because high balance fees have a different effect than high load factor fees on retirement wealth accumulation for lower-income workers. The lowest-fee pre-2008 PRA would require a subsidy equivalent to 0.17 percent of GDP to guarantee the minimum pension to all, while the lowest-fee post-2008 PRA would require a 0.15 percent subsidy. Schemes with lower fees provide higher accumulations of socialsecurity wealth. ${ }^{15}$

In sum, low-income workers who would receive the minimum pension guarantee in the PAYG are not affected by AFORE management fees because the government effectively bears the cost of these fees for such workers. Workers who could have obtained retirement benefits above the minimum pension guarantee under the no-fee scheme are affected by these fees.

To decrease the government burden in the scheme with fees, Tuesta (2011) proposes increasing the social quota from the current 5.5 percent of the minimum wage to 11 percent for all workers with income below four times the minimum wage and eliminating the social quota for workers earning at least four times the minimum wage. In that scenario, the impact of the fees scheme would be much higher for workers earning more than four times the minimum wage. This could provide incentives to underreport higher wages and thereby obtain the social quota.

The large loss of retirement funds under the different fee schemes in the PRA system suggests it may be necessary to have more competition in management fees in the AFOREs

where $T B_{f}^{D C}$ is the tax burden of the PRA system with fees, $T B_{n f}^{D C}$ is the tax burden of the PRA system with no fees, $C_{1 m w}$ is the number of contributors earning minimum wage in the 3rd quarter of 2012, GDP is the gross domestic product of Mexico in 2012, and LExp is the average life expectancy in years for a retiree (or, here, nine years).

${ }^{14} \mathrm{We}$ obtained these figures by computing the rate of increase between the amounts of retirement wealth provided by the government in the PAYG scenario and in the PRA systems with fees and without fees.

${ }^{15}$ Our estimates accord with Franco (2004). She uses the pre-2008 fee scheme, conducts Monte Carlo simulations on the wages of the contributors registered in the system in 2002, and uses Markov chains for the probability of contributing to the system in each period of time. She finds a present value of the annual fiscal cost of the government subsidy for the minimum pension guarantee of all contributors equaled 0.26 percent of GDP in 2002 . 
market (Calderón-Colín, Dominguez and Schwartz, 2008; Tapia and Yermo, 2008; Kritzer, Kay and Sinha, 2011). In Table 1, we include the retirement wealth accumulation with the fees scheme imposed by the least expensive AFORE, that is, those charging the lowest fees in the pre and post 2008 regimes. Representative contributors affiliated with the least-expensive AFOREs would improve significantly their retirement benefits: by 4.8 percent in comparison to the PAYG system before 2008 and by 8.4 percent since then. In the first case the total government subsidy would be 0.17 percent of GDP, 0.08 percent of GDP more than the PAYG scheme or 0.01 percent of GDP lower than the representative AFORE. In the post-2008 scheme the subsidy would be 0.15 percent of GDP, 0.07 percent of GDP higher than the PAYG scheme or 0.04 percent lower than the representative AFORE. 
Table 2

Composition of retirement wealth by level of income and regime (percentage of total account)

\begin{tabular}{|c|c|c|c|c|c|c|c|c|c|c|c|c|c|c|c|c|}
\hline \multirow[b]{2}{*}{$\begin{array}{l}\text { Labor } \\
\text { income } \\
\text { (number of } \\
\text { times the } \\
\text { minimum } \\
\text { wage) }\end{array}$} & \multicolumn{4}{|c|}{ PAYG } & \multicolumn{6}{|c|}{ PRA Before 2008} & \multicolumn{6}{|c|}{ PRA After 2008} \\
\hline & $\begin{array}{l}\text { Gover } \\
\text { nment }\end{array}$ & $\begin{array}{l}\text { Empl } \\
\text { oyer }\end{array}$ & $\begin{array}{l}\text { Empl } \\
\text { oyee }\end{array}$ & $\begin{array}{c}\text { est } \\
\text { (paid } \\
\text { by } \\
\text { gove } \\
\text { rnme } \\
\text { nt) }\end{array}$ & $\begin{array}{l}\text { Social } \\
\text { quota }\end{array}$ & $\begin{array}{l}\text { Go } \\
\text { ver } \\
\text { nm } \\
\text { ent }\end{array}$ & $\begin{array}{l}\text { Empl } \\
\text { oyer }\end{array}$ & $\begin{array}{l}\text { Empl } \\
\text { oyee }\end{array}$ & $\begin{array}{l}\text { AFO } \\
\text { RES }\end{array}$ & $\begin{array}{l}\text { Inte } \\
\text { rest }\end{array}$ & $\begin{array}{l}\text { Social } \\
\text { quota }\end{array}$ & $\begin{array}{c}\text { Gov } \\
\text { ern } \\
\text { me } \\
\text { nt }\end{array}$ & $\begin{array}{l}\text { Empl } \\
\text { oyer }\end{array}$ & $\begin{array}{l}\text { Empl } \\
\text { oyee }\end{array}$ & $\begin{array}{l}\text { AFO } \\
\text { RES }\end{array}$ & $\begin{array}{l}\text { Inte } \\
\text { rest }\end{array}$ \\
\hline 1 & 1.4 & 25.5 & 7.1 & 66.1 & 28.1 & 1.1 & 26.3 & 5.7 & -21.9 & 60.5 & 29.0 & 1.2 & 27.2 & 5.9 & -26.0 & 62.6 \\
\hline 2 & 2.0 & 36.8 & 10.3 & 51.0 & 18.9 & 1.5 & 35.4 & 7.7 & -26.3 & 62.8 & 18.8 & 1.5 & 35.3 & 7.7 & -26.0 & 62.6 \\
\hline 3 & 2.1 & 39.3 & 10.9 & 47.7 & 14.2 & 1.7 & 40.0 & 8.7 & -28.6 & 63.9 & 13.9 & 1.7 & 39.2 & 8.6 & -26.0 & 62.6 \\
\hline 4 & 2.3 & 42.4 & 11.8 & 43.5 & 11.4 & 1.9 & 42.8 & 9.3 & -29.9 & 64.6 & 11.1 & 1.8 & 41.4 & 9.1 & -26.0 & 62.6 \\
\hline . & . & . & . & . & . & . & . & . & . & . & . & . & . & . & . & . \\
\hline . & . & . & . & . & . & . & . & . & . & . & . & . & . & . & . & . \\
\hline . & & & & & & & . & & & & & . & . & . & . & \\
\hline 18 & 2.5 & 46.4 & 12.9 & 38.2 & 3.0 & 2.2 & 51.0 & 11.1 & -34.0 & 66.6 & 2.8 & 2.1 & 48.0 & 10.5 & -26.0 & 62.6 \\
\hline 19 & 2.5 & 46.4 & 12.9 & 38.2 & 2.9 & 2.2 & 51.2 & 11.2 & -34.1 & 66.6 & 2.7 & 2.1 & 48.1 & 10.5 & -26.0 & 62.6 \\
\hline 20 & 2.5 & 46.4 & 12.9 & 38.2 & 2.7 & 2.2 & 51.3 & 11.2 & -34.1 & 66.6 & 2.6 & 2.1 & 48.2 & 10.5 & -26.0 & 62.6 \\
\hline . & . & . & . & . & . & . & . & . & . & . & . & . & . & . & . & . \\
\hline . & . & . & . & . & . & . & . & . & . & . & . & . & . & . & . & . \\
\hline . &  & . & 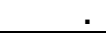 & & . & 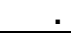 & . & . & . & & . & . & . & . & . & \\
\hline Average & 2.4 & 44.3 & 12.4 & 40.9 & 7.3 & 2.0 & 46.8 & 10.2 & -31.9 & 65.5 & 7.1 & 1.9 & 44.6 & 9.7 & -26.0 & 62.6 \\
\hline
\end{tabular}

Notes: Average is a simple algebraic average of the proportions of each item by all the levels of income.

SOURCE: Authors' calculation using data from Comisión Nacional del Sistema de Ahorro para el Retiro (CONSAR), 2012. 
Table 2 presents the composition of the retirement wealth over time for all regimes. In the PAYG system, employers make the highest proportion of worker's wage contributions for workers earning more than four times the minimum wage. Employer contributions constitute similar proportions of retirement wealth for similar workers in the PRA schemes, albeit slightly higher the pre-2008 PRA regime than in the post-2008 regime. The highest proportion of contributions to retirement funds of employees earning more than twice the minimum wage is in the PAYG system. The social quota, a fixed-amount contribution, represents a larger proportion of social security wealth in the PRA system after 2008 than before. In both PRA systems, interest is the largest component of accumulated retirement funds. Assuming a 5 percent real interest rate, interest accounts for 65.5 percent of retirement wealth in the pre-2008 system and 62.6 percent in the post-2008 system. Finally, Table 2 shows the drain of AFORE fees in total retirement benefits. On average, AFOREs drained 31.9 percent of total retirement benefits in the pre-2008 PRA system and 26.0 percent of such wealth in the post-2008 system.

As of November 2012, the Mexican PRA system had 48.2 million participants. The redistributive component of the Mexican social security system, that is, the minimum pension guarantee, in 2012 cost the government at least 2,692 million pesos or \$205.5 million U.S. dollars, while the entire social security system cost the government at least 124,934 million pesos or 9.5 billion U.S. dollars in the same year (Ministry of Finance, 2012). This included the cost of benefits for individuals retired under the PAYG system and the social quota. Such costs for the government are expected to exponentially increase in coming years. ${ }^{16}$

\footnotetext{
16 The daily minimum wage in Mexico City was 62.3 pesos in November 2012, as reported by the National Commission of Minimum Wages (Comisión Nacional de los Salarios Mínimos or CONASAMI, 2012).
} 


\section{Final Remarks}

In this paper, we calculated and compared social-security wealth accumulation under the Mexican PAYG and PRA systems. We also documented the impact of AFORE management fund fees-load-factor, balance, and accrued-interest - on individual retirement funds. The greatest losses in the PRA scheme before 2008 were due to the load-factor fee. To simplify the system, all fees were eliminated except for one that would be applied by all AFOREs. That one remaining fee-the balance fee-increased substantially. As a result, there was only a slight decrease in the loss of retirement wealth accumulation relative to the pre-2008 scheme.

We find that individuals were better off in the previous PAYG system than in the pre2008 PRA scheme. Yet they obtained similar social security benefits in both of these systems, depending on the performance of the real rate of return. With a real rate of return above 4.8 percent, the post 2008 PRA system performs better than the PAYG scheme, as does the pre-2008 system with a rate above 5.1 percent.

Yet for the retirement wealth of low-income workers in the PRA system to approximate that of the PAYG system, the defined-contribution system must have a low management-fee structure. By depleting pension wealth, management fees increase the number of persons qualifying for a subsidized minimum pension guarantee. This guarantee cost the government about 0.19 percent of the GDP in 2012, compared to 0.09 percent for the PAYG system and 0.18 percent for the pre-2008 PRA system. While 2008 reforms eliminated all fees but that on balance, they did not have a substantive positive effect on retirement wealth. Each type of fee has different effects on retirement wealth accumulation by level of labor income.

Previous studies suggest that mature PRA systems should produce lower fees. The PRA system has been in place in Mexico since 1997, almost 15 years. Tapia and Yermo (2008) and 
Dobronogov and Murthi (2005) suggest that large sunk costs of implementation may require AFOREs to apply high management fees when beginning operations. As years pass and the system matures, retirement-fund managers should become profitable because of economies of scale. Consequently, management fees should diminish. Moreover, in the long run, fees should be close to real costs (James, Smalhout and Vittas, 2001). Shah (1997) suggests that in Mexico the low responsiveness of management fees is due to the poor competition among AFOREspresenting a case similar to Chile, where fees have been expensive over time.

For Latin American countries, the structure of fees is generally not based on costs (Crabbe, 2005; Devesa, Rodríguez and Vidal, 2003), and competition has not apparently yielded a rational system of fees. Fees include costs of administration, competition, and those of sales personnel, differentiation, and advertisement (Crabbe, 2005). Advertisement costs have increased rather than reduced overall costs, offsetting economies of scale created by a large provider (Gill, Ozer and Tatucu, 2008).

Beyond the erosion of wealth accumulation of retirement funds in the mandatory account, the costs of saving in this system do not provide incentives to increase voluntary contributions. Moreover, the self-employed have no incentive to join the PRA because they can obtain higher returns from investing their contributions in other assets (Levy, 2008; Gill et al., 2005). AFOREs may be increasing incentives for workers to leave the formal sector and avoid mandatory contributions to the PRA system.

Some solutions have been suggested to reduce the AFORE costs. Moving to a structure where fees are applied as a percentage of accrued interest may reduce costs (Christensen, 2007; Martínez and Murcia, 2008). If more transparent and simpler information is provided to registrants, price competition among AFOREs could increase (Gutierrez, Serra and Fischer, 
2003; Hastings and Tejeda-Ashton, 2008). Shah (1997), Gutierrez, Serra, and Fischer (2003), and Corbo (2004) suggest opening the AFORE market to other financial institutions such as banks and insurance companies. Gill, et al. (2005) propose moving from a mandatory saving scheme to a flexible one in which an individual decides how much to contribute, possibly yielding a competitive voluntary savings market. Prieto (2005) recommended implementing a system in which the management fee is a unique percentage of the salaries of all workers registered to all AFOREs to make managers compete for workers' accounts on performance of returns and amount of retirement wealth. Prieto (2005) also asserts a deep asymmetry of information because the government has not advised workers on how to choose a fund manager but legally requires them to contribute to one of them.

The hazard of a lack of competition between fund managers is important to consider when implementing a PRA system (Mesa-Lago, 2002). Thus, it is crucial to pay attention to the fee structure when designing PRA systems and when studying how such a reform might affect economic preparation for retirement. Most Mexican workers are not enrolled to the AFORE with the lowest fees. This may suggest that workers are myopic when assessing the effects of fees on retirement wealth accumulation.

Our results suggest that informing participants of the impact of management fees on their retirement wealth, promoting financial literacy programs, and supporting mechanisms to help individuals optimize saving for retirement would increase the demand elasticity of the fees. Supplements to bank statements indicating how participants retirement wealth in their current AFORE compares to that of those with the highest and lowest management fees could also increase demand elasticity of the fees. This would help individuals understand the role of management fees in their retirement wealth. New schemes that provide transparency and 
promote competition among AFORES could improve the performance of the PRA system in Mexico. 


\section{Bibliography}

Aguila, E. 2011. "Personal Retirement Accounts and Saving", American Economic Journal: Economic Policy, Vol. 3, No. 4, 2011, pp. 1-24. http://www.aeaweb.org/articles.php?doi=10.1257/pol.3.4.1

Aguila, E. 2012. "Male Labor Force Participation and Social Security in Mexico", Working Paper 910, Santa Monica, CA: RAND Corporation, 2012. As of March 21, 2012:

http://www.rand.org/pubs/working papers/WR910.html

Aguila, Emma; Diaz, Claudia; Manqing Fu, Mary; Kapteyn, Arie and Pierson, Ashley. 2011. "Living Longer in Mexico: Income Security and Health". Santa Monica, CA: RAND Corporation. http://www.rand.org/pubs/monographs/MG1179

Arenas de Mesa, A; Mesa-Lago, C. 2006. "The Structural Pension Reform in Chile: Effects, Comparisons with Other Latin American Reforms, and Lessons", Oxford Review of Economic Policy, Vol. 22, No. 1, Spring, 2006, pp. 149-167. http://oxrep.oxfordjournals.org/content/22/1/149.abstract

BANXICO. 2012. "Exchange Rates" http://www.banxico.org.mx/portal-mercadocambiario/index.html

Benartzi, S., and Thaler, R. H.. 2001. "Naive diversification strategies in defined contribution saving plans", American Economic Review, Vol. 91, No. 1, pp. 79-98.

Beshears, John; Choi, James J.; Laibson, David and Madrian, Brigitte C. 2013. "Who Uses the Roth 401 (k), and How Do They Use It?", National Bureau of Economic Research.

Calderón-Colín, R.; Dominguez, E. E.; Schwartz, M. J. 2008. "Consumer Confusion: The Choice of Afore in Mexico", IMF Working Paper, No. 177. http://ssrn.com/paper=1266510

Choi, J. J.; Laibson D.; Madrian , B. C., and Metrick, A.. 2003. "Optimal defaults", American Economic Review, Vol. 93, No. 2, May, pp. 180-185.

Choi, James J.; Laibson, David; Madrian , Brigitte C., and Metrick, Andrew. 2005. "Optimal defaults and active decisions", National Bureau of Economic Research.

Christensen, Axel. 2007. "Chile: Lessons from a Maturing Pension System For Other Reforming Countries", paper presented at Financial and Private Sector Development Forum 2007, World Bank, Washington D.C.. As of March 22, 2012:

http://siteresources.worldbank.org/EXTFINANCIALSECTOR/Images/2828831306176187598/7951148-1306248954280/5cAxelChristensen.pdf

CONAPO. 2012. "Indicadores demográficos básicos 1990-2030". http://www.conapo.gob.mx/index.php?option=com content\&view=article\&id=125\&Itemid=203 
CONASAMI. 2012. "Salarios minimos vigentes a partir del 1 de enero de 2012". http://www.conasami.gob.mx/pdf/tabla salarios minimos/2012/01 01 2012.pdf

CONEVAL. 2010. "Methodology for Multidimensional Poverty Measurement in Mexico. An

Executuve Version".

http://web.coneval.gob.mx/rw/resource/coneval/med pobreza/MPMMPshortversion100903.pdf

CONSAR. 2003.2 Informativo SAR". http://www.consar.gob.mx/otra informacion/pdf/boletines sar/mayjun03.pdf

- 2012. "Información Estadística (Statistical Information),". http://www.consar.gob.mx/principal/estadisticas_sar.shtml

Corbo, V. 2004. "Policy Challenges of Population Aging and Pension Systems in Latin America", in Ellon, G.H., ed., Global Demographic Change: Economic Impacts and Policy Challenges., Kansas City: Federal Reserve Bank of Kansas City.

Crabbe, C.A. 2005. "A Quarter Century of Pension Reform in Latin America and the Caribbean: Lessons Learned and Next Steps", Washington, D.C.: Inter-American Development Bank.

Devesa, J. E.; Rodríguez R; Vidal C. 2003. "Medición y comparación internacional de los costes de administración para el afiliado en las cuentas individuales de capitalización", Revista Española de Financiación y Contabilidad, Vol. XXXII, No. 116, 2003, pp. 95-144. As of March 22, 2012:

http://aeca.es/pub/refc/articulos.php?id=0089

Dobronogov, A.; Murthi, M. 2005. "Administrative fees and costs of mandatory private pensions in transition economies", Journal of Pension Economics and Finance, Vol. 4, No. 01, 2005, pp. 31-55.

Franco, R. 2004. "Minimum Pension Guarantee in Mexico: Fiscal Cost and Implications". Dissertation. ITAM.

Gill, I. S.; Ozer, C.; Tatucu, R.. 2008. "What Can Countries in Other Regions Learn from Social Security Reform in Latin America?", The World Bank Research Observer, Vol. 23, No. 1, 2008, p. 57.

Gill, I; Packard, T; Pugatch, T; Yermo, J. 2005. "Rethinking Social Security in Latin America", International Social Security Review, Vol. 58, No. 2-3, 2005, pp. 71-96. http://dx.doi.org/10.1111/j.1468-246X.2005.00217.x

Grandolini, G; Cerda, L. 1998. "The 1997 Pension Reform in Mexico", Washington, D.C.: World Bank, 1998. http://ssrn.com/paper=604934

Gutierrez, R; Serra, P; Fischer, R. 2003. "The Effects of Privatization on Firms and on Social Welfare: The Chilean Case". Latin American Research Network Working Paper No. R-456, Washington, D.C.: Inter-American Development Bank. 
Hastings, J.S.; Tejeda-Ashton, L. 2008. "Financial Literacy, Information, and Demand Elasticity: Survey and Experimental Evidence from Mexico", National Bureau of Economic Research Working Paper Series 2008. As of December 2008:

http://www.nber.org/papers/w14538.pdf

James, E; Smalhout, J; Vittas, D. 2001. "Administrative costs and the organization of individual retirement account systems : a comparative perspective", Private Pensions Systems: Administrative Costs and Reforms: OECD, pp. 17-83. http://ideas.repec.org/p/wbk/wbrwps/2554.html

Kritzer, B.E.; Kay, S.J.; Sinha, T. 2011. "Next Generation of Individual Account Pension Reforms in Latin America", Social Security Bulletin, Vol. 71, No. 1, 2011, p. 35.

Kritzer, B. E. 2000. "Social Security Privatization in Latin America", Social Security Bulletin, Vol. 63, No. 2, 2000, pp. 17-37.

Levy, S. 2008 Good intentions, bad outcomes: social policy, informality, and economic growth in Mexico, Washington, DC: The Brookings Institution.

1996. "Ley de los Sistemas de Ahorro para el Retiro". http://www.diputados.gob.mx/LeyesBiblio/pdf/52.pdf

1992. "Ley Federal de Protección al Consumidor". http://www.diputados.gob.mx/LeyesBiblio/ref/lfpc.htm

Madrian, B. C. and Shea, D. F.. 2001. "The power of suggestion: Inertia in 401( $k$ ) participation and savings behavior", Quarterly Journal of Economics, Vol. 116, No. 4, Nov, 2001, pp. 1149-1187

Martínez, Ó; Murcia, A. 2008. "Sistema de comisiones de las Administradoras de Fondos de Pensiones en Colombia". Reporte de Estabilidad Financiera, Bogotá: Central Bank of Colombia. As of March 22, 2012:

http://www.banrep.org/documentos/publicaciones/report estab finan/2008/sistema.pdf

Mesa-Lago, C. 2002. "Reassessing Pension Reform in Chile and Other Countries in Latin America", paper presented at Seminar on Social Protection for the Poor in Asia and Latin America: Concepts and Experiences, Manila, Asian Development Bank.

Ministry of Finance. 2012. "Federal Budget for 2012 (Presupuesto de Egresos de la Federacion 2012)", Mexico.

Mitchell, O. 1999. "Evaluating Administrative Cost in México's AFORES Pension System", WP 1999-1, Philadelphia, PA: University of Pennsylvania Pension Research Council.

Prieto, S. V. 2005. "Para aumentar la competencia entre las AFP", Estudios públicos, ISSN 0716-1115, Vol. 98, 2005, pp. 87-142. 
Sánchez, D; de La Luz Juárez, G. 2008. "Los fondos de pensiones en México. Una evaluación de su primer década", Economía, Gestión y Desarrollo, Vol. 6, No. Diciembre, 2008, pp. 273 291.

Shah, H. C. 1997. "Toward Better Regulation of Private Pension Funds". World Bank Policy Research Working Paper 1791, Washington, D.C.: World Bank. http://ssrn.com/paper=43941

Sinha, T. 2002. "Cuanto cuesta la administracion de fondos? Presentation", Mexico City, Mexico: Instituto Tecnológico Autónomo de México. icpr.itam.mx/Pension2010/Sinha.ppt

Tapia, W.; Yermo, J. 2008. "Fees in individual account pension systems: A cross-country comparison", OECD Working Papers on Insurance and Private Pensions.

Tuesta, D. 2011. "A review of the pension systems in Latin America". Working Paper 11/15, Madrid: $\quad$ BBVA. $\quad$ http://www.bbvaresearch.com/KETD/fbin/mult/WP 1115 tcm348255095.pdf?ts $=2232012$ 